\title{
A framework to select innovations in patents to improve temporary edge protection systems in buildings
}

\author{
Método de seleção de inovações em patentes para \\ aperfeiçoamento dos sistemas de proteção periférica em \\ obras
}

\begin{tabular}{|c|c|}
\hline & $\begin{array}{l}\text { Letícia Nonnenmacher } \\
\text { Marcelo Fabiano Costella } \\
\text { Monike de Medeiros Costella } \\
\text { Tarcisio Abreu Saurin } \\
\text { Abstract }\end{array}$ \\
\hline & $\begin{array}{l}\text { his article presents a selection method of existing innovations in patents } \\
\text { that propose improvements in Temporary Edge Protection Systems } \\
\text { (TEPS). The method was divided into three stages. In stage 1, records } \\
\text { were collected related to TEPS from the patent filing databases of the } \\
\text { Instituto Nacional da Propriedade Industrial (National Institute of Industrial } \\
\text { Property, Brazil), the United States Patent and Trademark Office and the European } \\
\text { Patent Office. In stage 2, patents were selected based on the TEPS evaluation } \\
\text { protocol created by Peñaloza, Formoso and Saurin (2017), which examines safety, } \\
\text { efficiency and flexibility criteria. In stage 3, four patents were selected among the } \\
20 \text { patents found related to guard rails and three related to protection nets. Based } \\
\text { on the results, one invention stands out that uses hollow posts in protection } \\
\text { barriers, which allows for modular movement with safety and flexibility. The } \\
\text { framework proposed in this research is a useful resource for disseminating } \\
\text { techniques included in TEPS patent databases. }\end{array}$ \\
\hline $\begin{array}{r}\text { Iniversidade Comunitária da Região } \\
\text { de Chapecó } \\
\text { Chapecó - SC - Brasil }\end{array}$ & Keywords: Patents. Guard rails. Temporary edge protection systems. \\
\hline $\begin{array}{r}\text { Marcelo Fabiano Costella } \\
\text { Faculdade Meridional IMED } \\
\text { Universidade Comunitária da Região } \\
\text { de Chapecó } \\
\text { Chapecó - SC - Brasil }\end{array}$ & $\begin{array}{l}\text { Este artigo apresenta um método de seleção para inovações existentes em patentes } \\
\text { que busca propor aperfeiçoamentos em sistemas de proteção periférica (SPP). O } \\
\text { método foi dividido em três fases. Na fase } 1 \text { foram coletados registros } \\
\text { relacionados a SPP nas bases de depósito de patentes do Instituto Nacional da } \\
\text { Propriedade Industrial (Brasil), do United States Patent and Trademark Office }\end{array}$ \\
\hline $\begin{array}{l}\text { Monike de Medeiros Costella } \\
\text { Universidade Comunitária da Região } \\
\text { de Chapecó } \\
\text { Chapecó - SC - Brasil }\end{array}$ & $\begin{array}{l}\text { (Estados Unidos) e do European Patent Office (Europa). Na fase } 2 \text { foi } \\
\text { desenvolvido um método de seleção de inovações a partir do protocolo de } \\
\text { avaliação de SPP criado por Peñaloza, Formoso e Saurin (2015), o qual analisa } \\
\text { os critérios de segurança, eficiência e flexibilidade. Na fase 3, entre as } 20 \text { patentes } \\
\text { encontradas, foram selecionadas } 4 \text { referentes à guarda corpo e } 3 \text { referentes à tela }\end{array}$ \\
\hline $\begin{array}{r}\text { Tarcisio Abreu Saurin } \\
\text { Universidade Federal do Rio Grande } \\
\text { do Sul } \\
\text { Porto Alegre - RS - Brasil }\end{array}$ & $\begin{array}{l}\text { de proteção. Quanto aos resultados, destaca-se uma invenção que utiliza } \\
\text { montantes ocos em guarda-corpos, os quais permitem uma movimentação } \\
\text { modular com segurança e flexibilidade. O método proposto desta pesquisa é um } \\
\text { recurso aplicável e inovador para a disseminação das técnicas contidas em bases } \\
\text { de patentes nos sistemas de proteção periférica. }\end{array}$ \\
\hline & -corpo. Sistemas de proteção periférica. \\
\hline
\end{tabular}




\section{Introduction}

According to the International Labour Organization (ORGANIZAÇÃO..., 2013), a worker dies every 15 seconds and 160 fall victim to accidents in the world due to illnesses or accidents at work. Furthermore, Brazil is the fourth country with the highest number of fatal accidents. In Brazil, the construction industry accounts for the highest number of deaths and the number of recorded fatalities has been increasing each year. Falls from heights are some of the most common incidents due to the fact of not wearing personal protective equipment (PPE), not using collective protection equipment (CPE) and consequently the lack of prevention (ORGANIZAÇÃO..., 2013).

Temporary Edge Protection Systems (TEPS) are intended to protect workers against falls to a lower level and to retain certain materials using equipment as guard rails and nets. However, various construction companies manufacture their own systems without complying with the necessary specifications, showing low rates of compliance with regulatory requirements and making their physical protections ineffective (COSTELLA; JUNGES; PILZ, 2014).

Furthermore, there are few studies concerning new technologies for both individual and collective workplace safety equipment (XUE et al., 2014). Along the same lines, Gambatese and Hallowell (2011), as well as Hardie and Newell (2011) add that innovation in construction has been inadequate and that benefits concerning companies' success and competitiveness end up being lost due to not adopting new techniques and practices.

Due to the need of reducing accidents resulting from falls from heights and to adapt to new regulatory determinations, it is important for TEPS construction techniques to be reviewed and analysed so that devices include innovations that provide greater safety, usability, quality and economy. In their case studies, Ozorhon et al. (2010) point out improvements in health and safety indicators at the workplace as one of the many results obtained after adopting innovative measures in construction companies

Consequently, updated technological information on patent documents can be found. It not only provides a practical means of consultation, but also presents innovations in a simple and direct way, enabling a comparison between the proposed methods and those currently used in construction sites. Nevertheless, there is a lack of guidance in the literature in terms of how to explore new innovation in patents. In fact, there is a need to develop methods that help identify innovative parameters from patents that can be used directly. Therefore, this study proposes a framework to select innovations in patents as a means of proposing improvements in TEPS, focusing on guard rails and net protection systems.

\section{Theoretical background}

\section{Patents as a source of insights}

The World Intellectual Property Organization (2007) cites patents as a key component of intellectual property and is a legal way to protect any creation from the human mind. According to Corredoira and Banerjee (2015), patents provide a stimulus to technology and the economy.

Souza and Teixeira (2013) state that patents are regarded by the government as a way to encourage emerging new ideas and, consequently, new technologies. Through the patent system, inventors gain protection and rights over their patent for a certain period of time. After the established period of validity, the content of the patent is made fully available for public use and becomes a technology in the public domain.

All documents are stored on the online database of the country in which the request was made and the National Institute of Industrial Property (Instituto Nacional da Propriedade Industrial - INPI) is responsible for the storage of Brazilian patents, the USPTO (The United States Patent and Trademark Office) for American patents and the EPO (European Patent Office) for all European countries.

The Oficina Española de Patentes y Marcas (2012) explains that the process of searching for information concerning patents is simple as most documents are easily, freely and fully available on the Internet. Ouellette (2012) also states that this open disclosure provides various benefits, such as the possibility of researching unique ideas of patents by researchers, as well as the possibility of improvements as they are used.

Federman (2006) and INPI (INSTITUTO..., 2013) claim that a patent document should be up to date and complete and it should be described in such a way that a technician in the field could reproduce the invention. In addition to the wealth of information, Bröchner (2013) explains that patents are useful for formalising new technologies created through the collaboration and interaction between universities and industries, often being the link between the two. 
Most current patentometric studies (PAVANELLI; OLIVEIRA, 2012; FAGUNDES et al., 2014; JACOSKI; COSTELLA; RIGON, 2014) focus on conducting quantitative and qualitative surveys as a means to investigate the state of technological development in a certain field, company or institution. There are few authors who provide ways to extract information from patents focusing on innovations. Mazieri, Quoniam and Santos (2016) can be cited as examples of this. By using a model to extract and use patentometric information, these authors were able to show its potential in terms of contributing to innovative processes.

\section{Collective protection measures}

The Brazilian Regulatory Standard NR 35 (BRASIL, 2012) defines working at a height as any activity performed two meters above a lower level where there is a risk of falling. In item 35.4.1, it states that every time a task is characterized as working at a height, formal planning should be carried out and executed by a skilled worker.

The main dangerous situations related to falls from a height while constructing buildings include: slab edges; gaps in floors; gaps in the access to lifts, stairs and ramps; roof work and scaffolding and the assembly of structural elements. There are various ways to provide protection while working at heights, whether by risk analysis and prevention through design (TOOLE; CARPENTER, 2011) or by more direct strategies, such as using personal protective equipment. Choosing the equipment to be used is dependent on the type, adequacy and availability of the system, as well as the ability of workers to use the equipment safely (CAMERON; DUFF; GILLAN, 2005). Drozd and Kowalik (2014) cite collective equipment as the primary means of protection against falls from heights, and it should be adopted as a priority concerning personal protective equipment.

The Brazilian Regulatory Standard NR 18 (BRASIL, 2015) states that installing collective protection is required not only where there is a risk of workers falling, but also when there is danger of material falling and projecting. This also means the compulsory use of edge protection starting from the concreting services of laying the first slab. Costella, Junges and Pilz (2014) add that standard NR 18 is mostly a prescriptive standard, i.e., it does not establish performance requirements.

Cameron, Duff and Gillan (2005) cite guard rails and safety nets as examples of collective protection equipment. The former acts as a mean of prevention to the area and the latter to "secure" the worker in case he/she goes beyond the fall area. The guard rail system must follow the regulatory design and use specification standards, ensuring robustness by using rigid and resistant materials, and being fixed and installed properly to points on platforms or working and transit areas where there is a risk of people and material falling (LAN; DAIGLE, 2009; COSTELLA; JUNGES; PILZ, 2014). It is made up of an upper cross bar, intermediate posts, base and mount, with a cross arm brace, which is necessary if it is suspended (FUNDADENTRO, 2003).

In terms of the materials used for construction, NBR 14718 (ABNT, 2001) and UNE-IN 13374 (ASOCIACIÓN..., 2004) provide an option of using wood, steel or aluminum systems. Regarding the size of the guard rail, there are differences among the standards around the world. Standard NR 18 (BRASIL, 2015) defines a height of $1.20 \mathrm{~m}$ for the upper cross bar, $0.70 \mathrm{~m}$ for the intermediate post and $0.20 \mathrm{~m}$ for the toe board, and the existing gaps have to be covered by a net or similar device that ensures a secure closure. OSHA 1926.502 (OCCUPATIONAL..., 1996) establishes a final height of at least $1.10 \mathrm{~m}$ and the covering of the existing space between a work platform and the top of the system with a screen or mesh when there is no barrier with a minimum height of $53 \mathrm{~cm}$. UNEIN 13374 (ASOCIACIÓN..., 2004). On the other hand, a minimum height of $1.0 \mathrm{~m}$, a maximum distance of $2.50 \mathrm{~m}$ between the vertical beams and a minimum height of the base of $15 \mathrm{~cm}$ are established.

\section{Research method \\ Database selection and patent collection}

Document searches were carried out on the national website of the Brazilian INPI, the American USPTO and the European EPO. The patent databases regarding TEPS were not accessed by using keywords, but by classification codes of the IPC - International Patent Classification, which can be used in all databases. These codes were established in order to organize the vast range of patents registered throughout the world.

The IPC establishes a hierarchical classification of sections, classes, subclasses and groups, represented by letters and numbers, which is adopted in more than 100 countries, including Brazil, the United States and European countries. There are eight sections, named with the letters A to $\mathrm{H}$ according to the different technological fields of human, physical, chemical and construction needs, among others. Within these sections, there are different classes symbolized by numbers, which delimit the components belonging to each field. More details are included in the subclasses 
represented by letters and groups defined by numbers. Thus, the search codes follow the sequence: letter (section), number (class), letter (subclass) and numbers separated by a slash (group).

Since the aim of the study is to propose the improvement of TEPS, we decided to use classification code E04G 21/32. This refers to the sections Fixed Construction (E), Building Class (04) and subclass G Scaffolding; Forms; Shuttering; Building Implements or Other Building Aids or their Use; Handling Building Materials on the Site; Repairing, Breaking-up or Other Work on Existing Buildings. Group 21/32 covers safety or protective measures for persons while constructing buildings and is part of group 21/00 related to preparing, transporting or handling building materials in situ.

Three variables were proposed for discarding patents during their search in order to delimit the application of the established filters: the filing date, abstract and text. The filing date limit excluded those patents that were recorded until 2010 and patents that were identical to others. The most recent were kept. Patents were excluded by the abstract if they did not relate to TEPS. Those that were excluded because of the text referred to inventions of devices and components, but not to systems as a whole or to systems that were different to those established here. Patents were also excluded that did not have a complete document and those that were not written in Portuguese, English or Spanish.

To sum up, the filters were based on limiting criteria of the study and patents were only studied if they:

(a) were written in Portuguese, English or Spanish;

(b) had a filing date and complete description;

(c) had a filing date between 2010 and 2015; and

(d) had net protection, excluding other inventions.

\section{Application of the TEPS evaluation protocol}

Peñaloza, Formoso and Saurin (2017) identified 34 requirements to be met by TEPS, distributing them into 3 categories: safety, efficiency and flexibility. Safety requirements mostly originate from standards, such as minimizing the risk of falling and the strength of the system. Efficiency is related to aspects such as ergonomics, management and costs. On the other hand, flexibility means adapting to the construction site arrangements and different construction techniques.
Regarding the main problems that cause noncompliance to the performance of each requirement, Peñaloza, Formoso and Saurin (2017) emphasize the lack of safety when installing and removing systems in the category "Safety", exposing the worker's body over the edge and increasing the risk of falling. In the category of "Efficiency", the main question considered was the use of nails as a way to secure the systems, resulting in excessive effort, inadequate postures and low productivity in assembly and disassembly activities. Concerning the category "Flexibility", the fact was emphasized that in some cases the guard rail should be removed to allow for the entry of materials over the edge, affecting the stability of the system.

Implementing the protocol defined the selection of innovations in the existing patents. The patents were evaluated based on the performance requirements relating to safety, efficiency and flexibility and percentages of adherence were allocated to the categories. One hundred percent was adopted for cases of full adherence, $50 \%$ for partial adherence and $0 \%$ for cases with no adherence or a lack of information.

Peñaloza, Formoso and Saurin (2017) categorized the requirements selected into design and use. Design refers to specifications such as strength, reusing equipment, size and features of its components. The use requirements, on the other hand, include evaluating the already installed system, such as its assembly and disassembly method. Only the design requirements were used to evaluate the patents. The use requirements were not subject to analysis in this patentometric study as the informative nature of a patent document focuses on the development method of the invention.

\section{Selecting and identifying innovations and improvement proposals}

Those inventions that, by applying the evaluation protocol, showed an average adherence to the safety, efficiency and flexibility categories exceeding $50 \%$ were selected for presentation and discussion. These inventions were classified by the type of system. The results of the patents for guard rails were presented first, followed by inventions related to protection nets. For each one of the selected patents, a summary is presented with a respective discussion on the innovation related to TEPS, pointing to the possible applications of the proposals identified in each patent. 


\section{Results}

\section{Selected Patents}

The search was limited by the classification code E04G 21/32, returning a total of 559 patents with documents related to TEPS, considering results of all the databases. However, when the search filters were applied, only 20 were selected for the study (Figure 1).

In the case of the INPI, the search performed with the classification code E04G 21/32 returned 38 documents, although only 3 met the search requirements. 21 patents were found in the USPTO and 3 were collected after applying the filters.
The EPO was the base that returned the greatest number of documents. The search involved more than 500 patents with dates from 1991 to 2015 . However, only the first 500 patents were consulted and they were not organized based on the filing date. The patents were presented in a mixed form. Once the search was completed, many patents did not refer to TEPS or they did not meet the adopted language and period limit. As such, 14 documents were selected. Figure 1 illustrates the filtering and collecting process of documents from the search databases and the total number of selected patents after filtering. After applying the filters, 20 patents were selected, which are described in Figure 2.

Figure 1 - Results of adopting the inclusion and exclusion criteria for patents related to TEPS

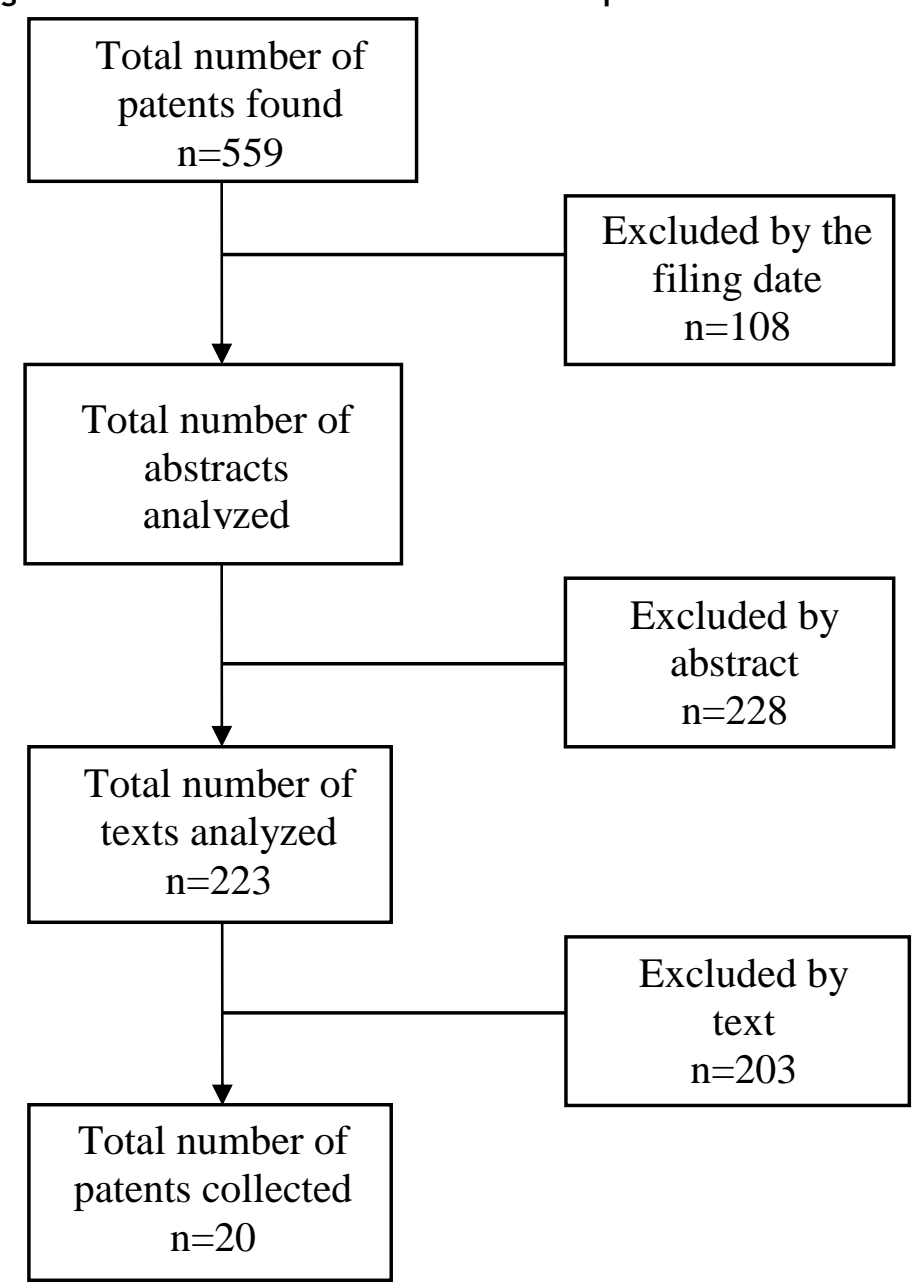


Figure 2 - Patents collected after applying the selection filters

\begin{tabular}{|c|c|}
\hline INVENTION & DESCRIPTION \\
\hline $\begin{array}{l}\text { A Modular Barrier System (THRUSH; } \\
\text { VOS; WHITE, 2013) }\end{array}$ & $\begin{array}{l}\text { Modular protective barrier (footer) formed by elongated bars in } \\
\text { rigid plastic, aluminum or metal, used against the projection of } \\
\text { materials in edges in construction sites. }\end{array}$ \\
\hline $\begin{array}{c}\text { Building Roof Safety Assembly Having } \\
\text { a Barrier and Ladder Restraint } \\
\text { (BUDZIAK; BUDZIAK; BUDZIAK, } \\
\text { 2013) }\end{array}$ & $\begin{array}{l}\text { Safety system with attached ladder in plastic or metal, for roof } \\
\text { work. }\end{array}$ \\
\hline $\begin{array}{l}\text { Fall Protection Equipment with Safety } \\
\text { Net for Civil Construction (AFETAL, } \\
\text { 2013) }\end{array}$ & $\begin{array}{l}\text { Fall protection system for people and materials, made up of a } \\
\text { vertical rod and eye bolts to insert ropes that form a collecting } \\
\text { bag. }\end{array}$ \\
\hline $\begin{array}{l}\text { Fall Protection System (AMADON et } \\
\qquad a l ., \text { 2012) }\end{array}$ & $\begin{array}{l}\text { System formed by a protection net and adjustable columns to } \\
\text { protect workers in the event of a fall from heights and stopping } \\
\text { the projection of materials. }\end{array}$ \\
\hline $\begin{array}{l}\text { Fence for Use as Barrier Installation } \\
\text { (RAMON, 2012) }\end{array}$ & $\begin{array}{l}\text { Guard rail consisting of parts with a clamping system to protect } \\
\text { workers and materials against falls from heights. }\end{array}$ \\
\hline $\begin{array}{l}\text { Improved Frame for Climbing Screen } \\
\text { (ROSATI, 2012) }\end{array}$ & $\begin{array}{l}\text { Adjustable metal barrier to protect against people and projection } \\
\text { of materials falling. }\end{array}$ \\
\hline $\begin{array}{l}\text { Perimeter Screen with Rotating Debris } \\
\text { Retainer (MARK, 2011) }\end{array}$ & $\begin{array}{l}\text { Screen system made up of a supporting structure and a retainer } \\
\text { for mobile debris, used in edges of construction sites to capture } \\
\text { projected debris from falling on to lower levels. }\end{array}$ \\
\hline $\begin{array}{l}\text { Removable Safety Barrier (DITTA; } \\
\text { DITTA; DITTA, 2014) }\end{array}$ & $\begin{array}{l}\text { Removable protection barrier (guard rail) in steel and wood to } \\
\text { protect against the projection of debris and people falling during } \\
\text { the excavation phase of the work. }\end{array}$ \\
\hline $\begin{array}{l}\text { Riser Safety Arrangement for Open } \\
\text { Stair (JARRET; STREET; } \\
\text { WARNAMBOOL, 2013) } \\
\end{array}$ & $\begin{array}{l}\text { Protection net against the projection of debris and tools, used in } \\
\text { the gaps between the steps of open ladders. }\end{array}$ \\
\hline $\begin{array}{l}\text { Safety Barrier (DELIC; } \\
\text { PAPAYIANNERIS, 2010) }\end{array}$ & $\begin{array}{l}\text { Protection barrier formed by a base plate, vertical posts and } \\
\text { horizontal bars that prevent workers from falling on to lower } \\
\text { levels. }\end{array}$ \\
\hline Safety Barrier (SVEDBERG, 2013) & $\begin{array}{l}\text { A mobile protection barrier with hollow vertical bars and a } \\
\text { screen system, used to prevent workers from falling in } \\
\text { construction sites. }\end{array}$ \\
\hline $\begin{array}{c}\text { Safety Barrier Netting System with } \\
\text { Rigid Panel Net Supports and Stopper } \\
\text { Mechanisms (BLINN, 2012) } \\
\end{array}$ & $\begin{array}{l}\text { An aluminum barrier providing simultaneous protection against } \\
\text { the fall of workers and materials. }\end{array}$ \\
\hline Safety Guard Rail (WILLIAMS, 2010) & $\begin{array}{l}\text { A protection barrier against workers falling from heights during } \\
\text { work done on sloping and horizontal roofs. }\end{array}$ \\
\hline $\begin{array}{l}\text { Safety Rail System (FRITSCH; } \\
\text { ROBERTS, 2013) }\end{array}$ & $\begin{array}{l}\text { Protection barrier formed by vertical and horizontal bars, used to } \\
\text { implement the structural masonry phase. }\end{array}$ \\
\hline $\begin{array}{l}\text { Safety Rail System (SIDLA; } \\
\text { STOFFELS, 2013) }\end{array}$ & $\begin{array}{l}\text { Guard rail formed by vertical and horizontal beams joined by } \\
\text { connectors to protect workers against falls from heights. }\end{array}$ \\
\hline $\begin{array}{l}\text { Safety Rail System and Method for } \\
\text { Using Same (CHILTON, 2011) }\end{array}$ & $\begin{array}{l}\text { Protection barrier formed by primary and secondary parts } \\
\text { through metal hinges and pins. }\end{array}$ \\
\hline Safety System (SMITH, 2011) & $\begin{array}{l}\text { Guard rail to protect workers against falls from heights, formed } \\
\text { by vertical steel bars and horizontal aluminum, wood or rigid } \\
\text { plastic bars. }\end{array}$ \\
\hline Scaffolding Safety Mesh (SONG, 2011) & $\begin{array}{l}\text { Protection system made up of polymer belts and a screen, used } \\
\text { as a complement for safety barriers or scaffolding. }\end{array}$ \\
\hline $\begin{array}{l}\text { Protection System for Works } \\
\text { (NOVAES, 2012) }\end{array}$ & $\begin{array}{l}\text { Protection system formed by a guard rail and hooks to attach } \\
\text { trays, used against falling materials and workers on the edge. }\end{array}$ \\
\hline $\begin{array}{c}\text { Height-Limiting Fall Protection System } \\
\text { with Safety Net (SILVA, 2011) }\end{array}$ & $\begin{array}{l}\text { System to simultaneously protect against falling persons and } \\
\text { objects, formed by vertical metallic tubes and a safety net. }\end{array}$ \\
\hline
\end{tabular}




\section{Evaluation of requirements}

After implementing the evaluation protocol, the percentage of adherence for the safety category (Figure 3) was 29\%. Requirements 1 and 2 were the most met, which relate to protection against people, materials and tools from falling. Requirement 3 was the least satisfied, which indicates that most patents collected did not specify the strength offered by the invention equipment. Requirements 6,9 and 10 were not covered by any of the documents found, which may be interpreted as an opportunity to further describe the selected TEPS design and technical specifications.
The "Efficiency" category showed an adherence of $29 \%$ (Figure 4), just as the category Safety. Requirement 2 was the most satisfied and requirement 3 had the lowest degree of adherence, as only one patent had information about the weight of the invention. The possibility of reusing the equipment in construction sites or in future construction sites, shown by Requirement 1 , was explicitly stated in 12 out of the 20 patents, having the greatest degree of adherence.

Concerning the category Flexibility, it had the highest percentage of adherence (34\%) among the 3 categories under study (Figure 5). All requirements in this category complied with at least one of the selected patents.

Figure 3 - Evaluation of safety requirements

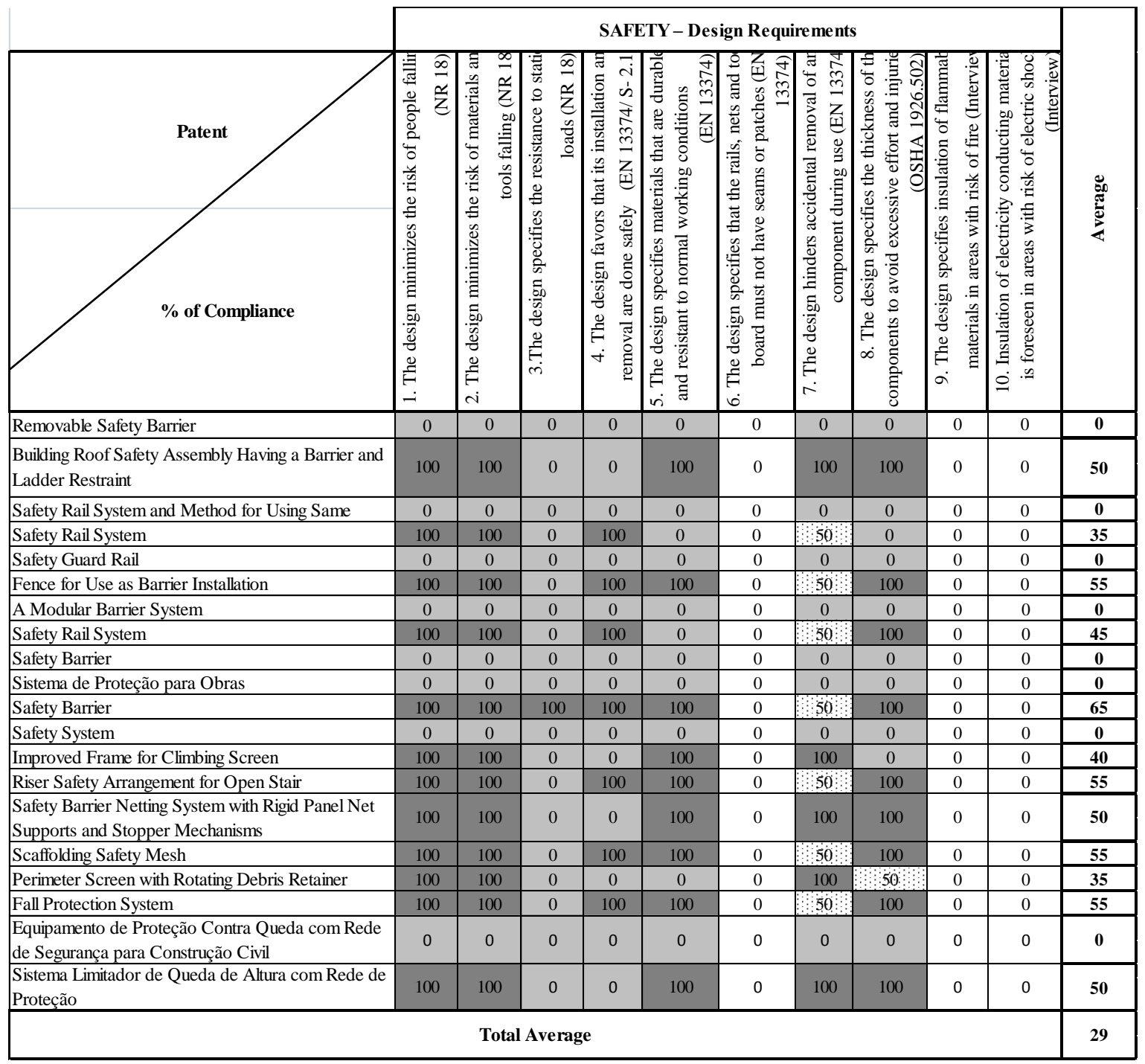


Figure 4 - Evaluation of efficiency requirements

\begin{tabular}{|c|c|c|c|c|c|c|}
\hline \multirow[b]{2}{*}{ \% of Compliance } & \multicolumn{5}{|c|}{ EFFICIENCY - Design Requirements } & \multirow[b]{2}{*}{ 苞 } \\
\hline & 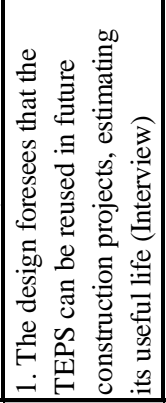 & 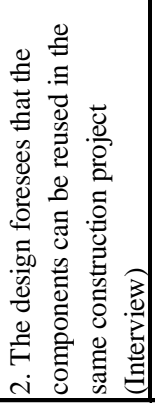 & 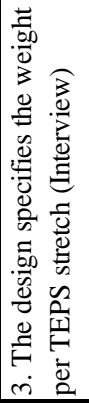 & 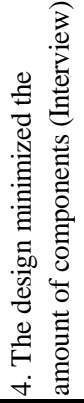 & 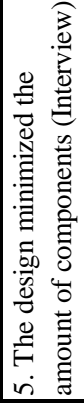 & \\
\hline Removable Safety Barrier & 0 & 0 & 0 & 0 & 0 & $\mathbf{0}$ \\
\hline $\begin{array}{l}\text { Building Roof Safety Assembly Having a Barrier and Ladder } \\
\text { Restraint }\end{array}$ & 50 & 100 & 0 & 0 & 0 & 30 \\
\hline Safety Rail System and Method for Using Same & 0 & 0 & 0 & 0 & 0 & $\mathbf{0}$ \\
\hline Safety Rail System & 50 & 100 & 0 & 50 & 0 & 50 \\
\hline Safety Guard Rail & 0 & 0 & 0 & 0 & 0 & $\mathbf{0}$ \\
\hline Fence for Use as Barrier Installation & 50 & 100 & 0 & 100 & 0 & 50 \\
\hline A Modular Barrier System & 0 & 0 & 0 & 0 & 0 & $\mathbf{0}$ \\
\hline Safety Rail System & 50 & 100 & 0 & 100 & 0 & 50 \\
\hline Safety Barrier & 0 & 0 & 0 & 0 & 0 & $\mathbf{0}$ \\
\hline Protection system for works & 0 & 0 & 0 & 0 & 0 & $\mathbf{0}$ \\
\hline Safety Barrier & 50 & 100 & 100 & 100 & 0 & 70 \\
\hline Safety System & 0 & 0 & 0 & 0 & 0 & $\mathbf{0}$ \\
\hline Improved Frame for Climbing Screen & 50 & 100 & 0 & 0 & 0 & 30 \\
\hline Riser Safety Arrangement for Open Stair & 100 & 100 & 0 & 100 & 0 & 60 \\
\hline $\begin{array}{l}\text { Safety Barrier Netting System with Rigid Panel Net Supports } \\
\text { and Stopper Mechanisms }\end{array}$ & 50 & 100 & 0 & 0 & 0 & 30 \\
\hline Scaffolding Safety Mesh & 50 & 100 & 0 & 100 & 100 & 70 \\
\hline Perimeter Screen with Rotating Debris Retainer & 50 & 100 & 0 & 0 & 100 & $\mathbf{5 0}$ \\
\hline Fall Protection System & 50 & 100 & 0 & 100 & 100 & 70 \\
\hline $\begin{array}{l}\text { Fall Protection Equipment with Safety Net for Civil } \\
\text { Construction }\end{array}$ & 0 & 0 & 0 & 0 & 0 & $\mathbf{0}$ \\
\hline Height-Limiting Fall Protection System with Safety Net & 50 & 100 & 0 & 0 & 0 & 30 \\
\hline Total A & rage & & & & & 29 \\
\hline
\end{tabular}

Requirement 2 was the most satisfied, as 12 out of the 20 patents had information about the possibility of using the system in all the construction stages. Concerning the adaptation of the invention to different construction technologies, only one of the patents met this requirement $100 \%$ and 5 met it partially (50\%), which made requirement 6 the least satisfied.

Figure 6 shows the percentages of adherence to the safety, efficiency and flexibility categories in order to select only those patents with the best performance regarding the requirements met. The patents that reached a result greater than $50 \%$ were highlighted, totaling a final selection of 7 patents to identify innovations and improvement proposals.

\section{Analysis of the selected innovations}

\section{Guard rails}

Many contributions were identified in the selected patents, mainly regarding the category flexibility. For instance, the invention Building Roof Safety Assembly Having a Barrier and Ladder Restraint (BUDZIAK; BUDZIAK; BUDZIAK, 2013) proposes a protection barrier coupled to a metal platform with a ladder built into the system (Figure 7). This provides improved effectiveness for work done on roofs, such as construction, renovation and maintenance work where an access way and a safe and practical horizontal plane need to be created, so that tools and materials can be transported and deposited near the site. The innovation lies in integrating the three aspects - platform, guard rail and ladder - in one single piece of equipment, which adds value in terms of safety and flexibility. 
Figure 5 - Evaluation of flexibility requirements

\begin{tabular}{|c|c|c|c|c|c|c|c|}
\hline \multirow[b]{2}{*}{$\%$ of Compliance } & \multicolumn{6}{|c|}{ FLEXIBILITY - Design Requirements } & \multirow[b]{2}{*}{$\begin{array}{l}8 \\
\frac{\pi}{2} \\
\frac{\pi}{2}\end{array}$} \\
\hline & 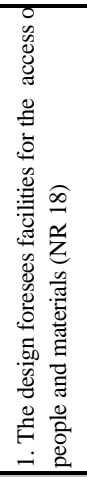 & 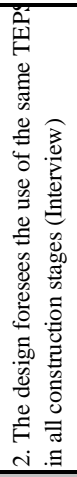 & 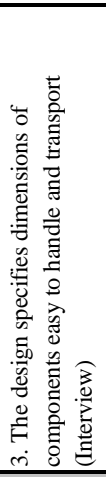 & 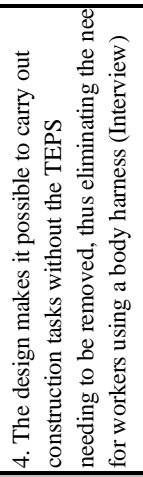 & 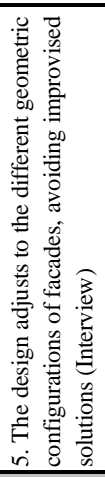 & 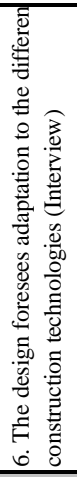 & \\
\hline Removable Safety Barrier & 0 & 0 & 0 & 0 & 0 & 0 & $\mathbf{0}$ \\
\hline $\begin{array}{l}\text { Building Roof Safety Assembly Having a Barrier and Ladder } \\
\text { Restraint }\end{array}$ & 100 & 100 & 50 & 100 & 100 & 100 & 91 \\
\hline Safety Rail System and Method for Using Same & 0 & 0 & 0 & 0 & 0 & 0 & $\mathbf{0}$ \\
\hline Safety Rail System & 0 & 100 & 0 & 0 & 50 & 0 & 25 \\
\hline Safety Guard Rail & 0 & 0 & 0 & 0 & 0 & 0 & $\mathbf{0}$ \\
\hline Fence for Use as Barrier Installation & 100 & 100 & 100 & 0 & 50 & 0 & 58 \\
\hline A Modular Barrier System & 0 & 0 & 0 & 0 & 0 & 0 & $\mathbf{0}$ \\
\hline Safety Rail System & 0 & 100 & 100 & 50 & 100 & 0 & 58 \\
\hline Safety Barrier & 0 & 0 & 0 & 0 & 0 & 0 & $\mathbf{0}$ \\
\hline Protection system for works & 0 & 0 & 0 & 0 & 0 & 0 & $\mathbf{0}$ \\
\hline Safety Barrier & 100 & 100 & 100 & 100 & 100 & 0 & 83 \\
\hline Safety System & 0 & 0 & 0 & 0 & 0 & 0 & $\mathbf{0}$ \\
\hline Improved Frame for Climbing Screen & 0 & 100 & 0 & 0 & 50 & 0 & 25 \\
\hline Riser Safety Arrangement for Open Stair & 100 & 100 & 100 & 100 & 100 & 0 & 83 \\
\hline $\begin{array}{l}\text { Safety Barrier Netting System with Rigid Panel Net Supports } \\
\text { and Stopper Mechanisms }\end{array}$ & 0 & 100 & 0 & 0 & 50 & 50 & 33 \\
\hline Scaffolding Safety Mesh & 0 & 100 & 100 & 0 & 50 & $50:$ & 50 \\
\hline Perimeter Screen with Rotating Debris Retainer & 0 & 100 & 0 & 0 & 50 & 50 & 33 \\
\hline Fall Protection System & 100 & 100 & 100 & 100 & 100 & 50 & 91 \\
\hline $\begin{array}{l}\text { Fall Protection Equipment with Safety Net for Civil } \\
\text { Construction }\end{array}$ & 0 & 0 & 0 & 0 & 0 & 0 & $\mathbf{0}$ \\
\hline Height-Limiting Fall Protection System with Safety Net & 100 & 100 & 0 & 0 & 50 & 50 & 50 \\
\hline \multicolumn{7}{|c|}{ Total Average } & 34 \\
\hline
\end{tabular}

Figure 6- Final average of adherence to the performance requirements

\begin{tabular}{|c|c|c|c|c|}
\hline Invention & Safety & Efficiency & Flexibility & Average \\
\hline Removable Safety Barrier & 0 & 0 & 0 & $\mathbf{0}$ \\
\hline Building Roof Safety Assembly Having a Barrier and Ladder Restraint & 50 & 30 & 91 & 57 \\
\hline Safety Rail System and Method for Using Same & 0 & 0 & 0 & $\mathbf{0}$ \\
\hline Safety Rail System & 35 & 50 & 25 & 37 \\
\hline Safety Guard Rail & 0 & 0 & 0 & $\mathbf{0}$ \\
\hline Safety Rail System & 45 & 50 & 58 & 51 \\
\hline Safety Barrier & 0 & 0 & 0 & $\mathbf{0}$ \\
\hline Protection System for Works & 0 & 0 & 0 & $\mathbf{0}$ \\
\hline Safety Barrier & 65 & 70 & 83 & 73 \\
\hline Safety System & 0 & 0 & 0 & $\mathbf{0}$ \\
\hline Scaffolding Safety Mesh & 55 & 70 & 50 & 58 \\
\hline Perimeter Screen with Rotating Debris Retainer & 35 & 50 & 33 & 39 \\
\hline Fall Protection System & 55 & 70 & 91 & 72 \\
\hline Fall Protection Equipment with Safety Net for Civil Construction & 0 & 0 & 0 & $\mathbf{0}$ \\
\hline Height-Limiting Fall Protection System with Safety Net & 50 & 30 & 50 & 43 \\
\hline
\end{tabular}


Figure 7 - Building Roof Safety Assembly Having a Barrier and Ladder Restraint

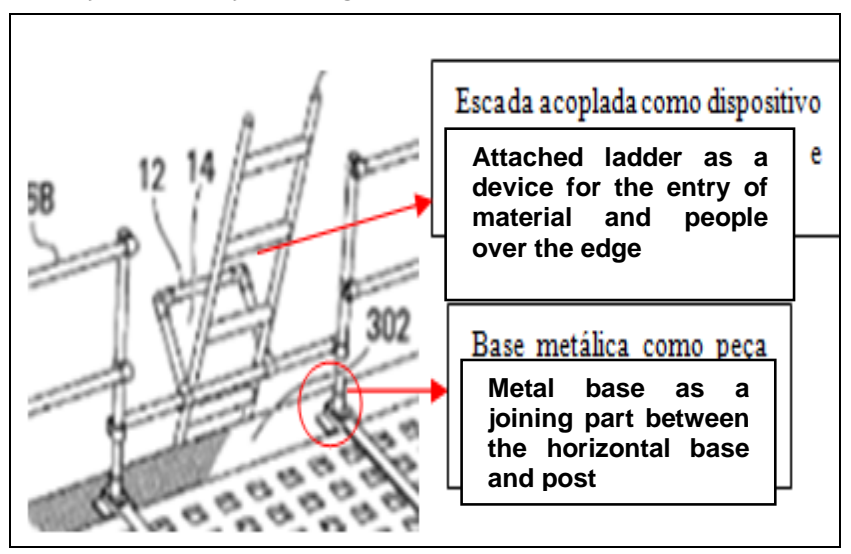

Source: Budziak, Budziak and Budziak (2013).

The second invention selected, called Fence for Use as Barrier Installation (RAMON, 2012), is easy to assemble and disassemble based on a fitting system, making it possible to transport the parts individually. It can be adapted to the horizontal plane and can create openings without having to completely disassemble the system. Its characteristics are similar to the previous invention and different sizes of the system can be made using the lock pins, which can be seen in Figure 8. The possibility of changing the size of the parts can produce different configurations for various applications, such as isolating areas, creating passages on construction sites, as well as the guard rail function.

Regarding the third patent, the Safety Rail System (FRITSCH; ROBERTS, 2013) proposes a method for installing the posts (Figure 9). It can be fixed while implementing the concrete structure of the work without drilling or using nails. Another positive aspect is the possibility of using this collective protective equipment while implementing the structure process, which is often neglected because of the difficult installation, exposing workers to hazards. The invention facilitates the handling of the lock pins without needing to completely disassemble the components. Moreover, it can create openings by releasing the pins that connect the part to the base in the structure used as a support.

The fourth document selected referring to guard rails is the Safety Barrier (SVEDBERG, 2013), which proposes a protection barrier with the possibility of openings through modules that work similarly to opening gates, as illustrated in Figure 10. Not only can this invention adapt to the horizontal plane and the consequent formation of different arrangements, its main advantage is that materials can enter without needing to disassemble the system, which is a problem faced in construction sites because of the lack of flexibility of the current protection systems.

\section{Protection nets}

The main innovations proposed by the protection net inventions are focused on improvements in the attachment and joining methods between the component parts of the system.

The Riser Safety Arrangement for Open Stairs (JARRET; STREET; WARNAMBOOL, 2013) presents a system of removable clips as a way of joining safety nets and an attachment structure, as shown in Figure 11. This invention provides a reduction in handling, assembly and dismantling efforts, as it replaces the current use of nails or screws. 
Figure 8 - Fence for Use as Barrier Installation

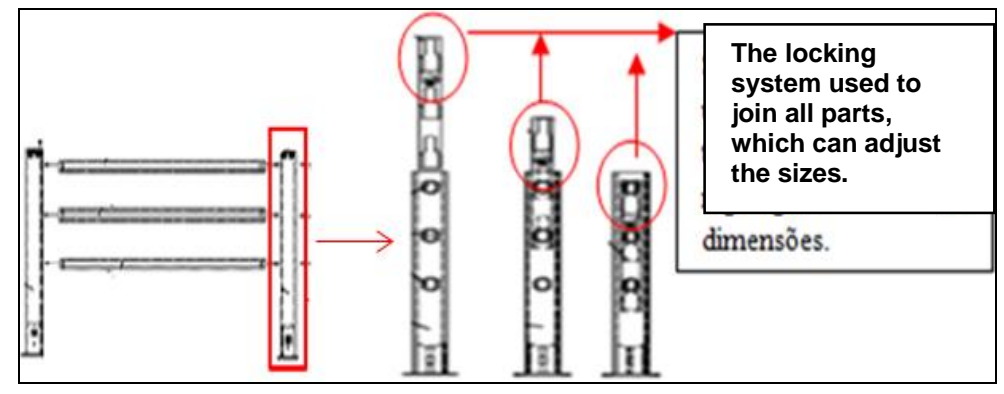

Source: Ramon (2012).

Figure 9 - Safety Rail System

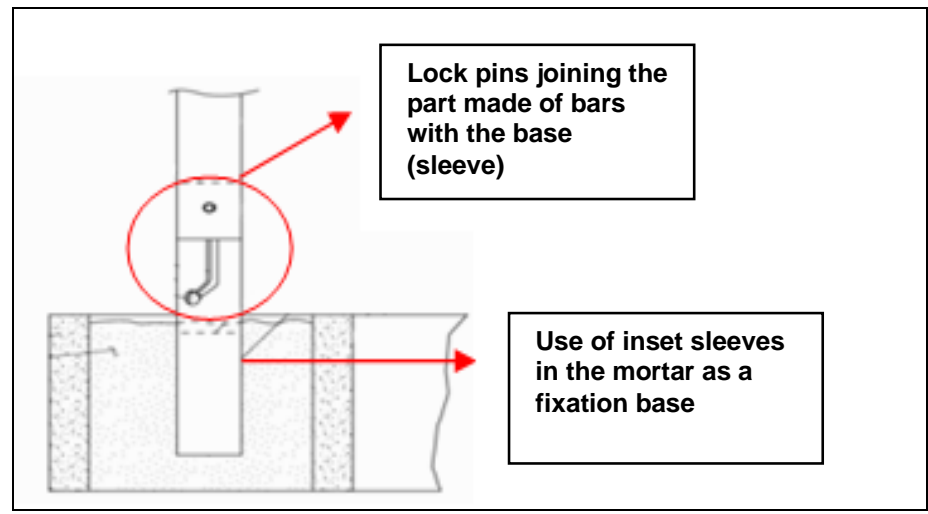

Source: Fritsch and Roberts (2013).

Figure 10 - Safety Barrier

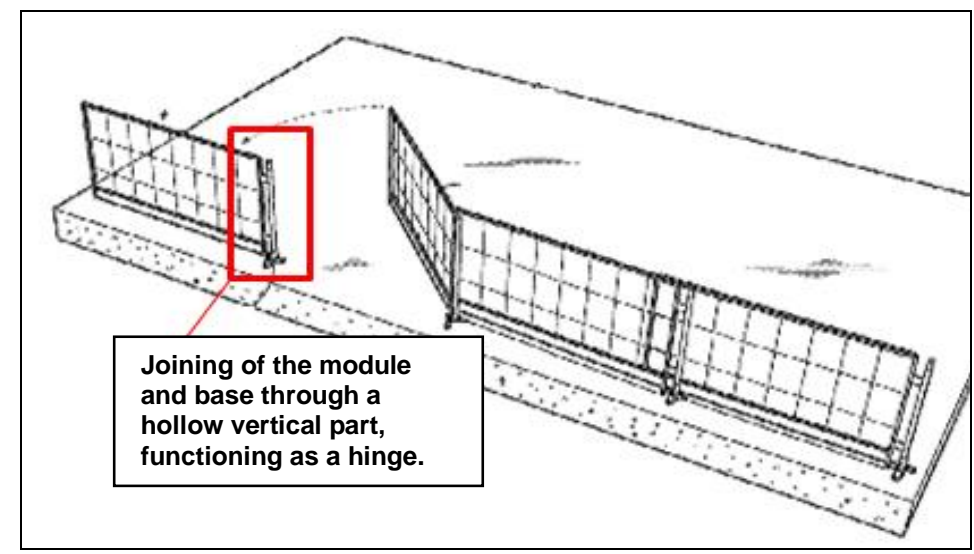

Source: Svedberg (2013).

Figure 11 - Riser Safety Arrangement for Open Stairs

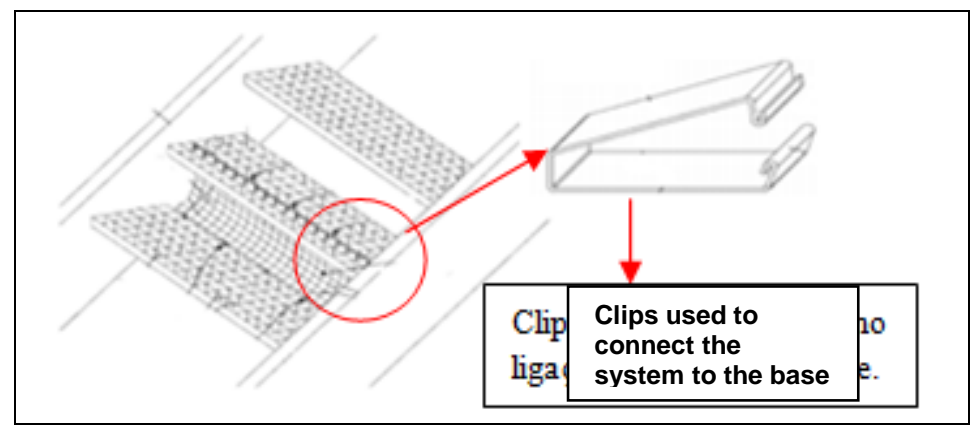

Source: Jarret, Street and Warnambool (2013). 
Another similar way is presented by the patent Scaffolding Safety Mesh (SONG, 2011), which proposes a joining method based on adhesives subjected to fusion or clamps. The configuration can be seen in Figure 12.

In addition to gaps in the stairs, the methods may be adopted in sidings to show hazardous locations in construction sites. They can also be used in guard rails that include textile materials instead of wooden or metal cross beams or other resistant components.

Finally, the patent Fall Protection System (AMADON et al., 2012) incorporates means that can replace the use of nails or screws to join nets and mounts, reducing efforts and exposure to risk. Using adjustable vertical posts and clamps to connect components provides flexibility in the modulations, they are easy to ship and handle, and easy to assemble and disassemble (Figure 13). The system can be used for guard rails of horizontal and sloped platforms, for vertical and horizontal nets and for isolating areas and closing off dangerous gaps.

\section{Discussion}

While patents may be a source of insights for improving the TEPS design, professionals could be discouraged from taking advantage of this body of knowledge, given the large number of patents and the lack of methods to select and analyse the innovations of interest. Taking this into account, the framework proposed in this paper is a contribution, as it presents a set of steps for selecting and analysing innovations in TEPS. In particular, using requirement categories (i.e. safety, efficiency and flexibility) has made it easier to identify different types of innovations and have a broader view of the TEPS performance within each category. Furthermore, the patent inventors can also benefit from the framework, as they can pinpoint opportunities to improve the design.

It is also worth noting that the framework emphasis on efficiency and flexibility requirements helped to identify innovations that can be useful in a wide range of different regulatory environments in different countries. In fact, the flexibility requirements had the highest average score among the selected patents (73), while the requirements related to efficiency (57) and safety (54) obtained lower values.

For instance, some of the selected patent documents (e.g. Fence for Use as Barrier Installation by Ramon, 2012 and Safety Barrier by Svedberg, 2013) provided the option to change the sizes and spacing between the guardrails, offering the ability of complying with different regulations related to these topics. This example also illustrates relationships between the requirements, as it shows how a flexibility characteristic of the TEPS (i.e. change spacing) can be useful for complying with safety requirements (i.e. guard rails set at certain heights)

Figure 12 - Scaffolding Safety Mesh

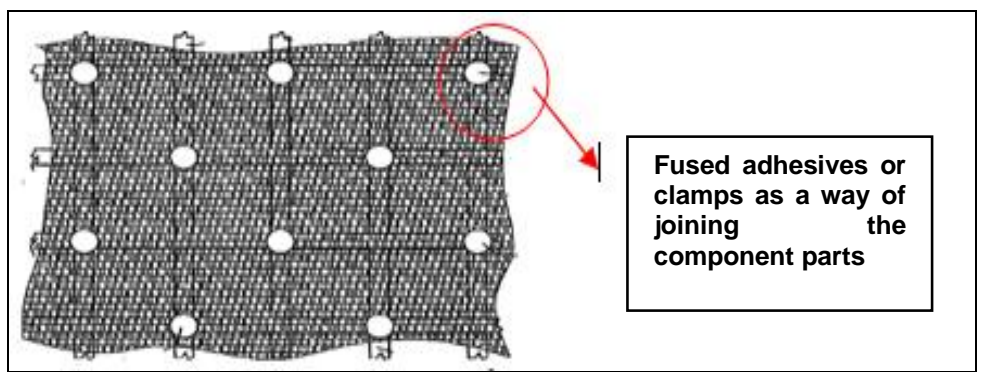

Source: Song (2011).

Figure 13 - Fall Protection System

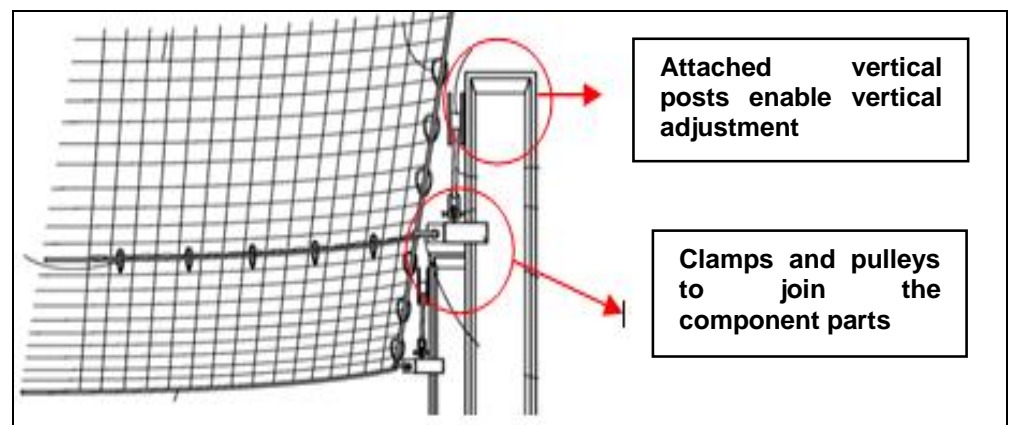

Source: Amadon et al. (2012). 
Another example is that other selected patents (e.g. Building Roof Safety Assembly Having a Barrier and Ladder Restraint by Budziak, Budziak and Budziak (2013) and Fall Protection System by Amadon et al. (2012)) presented $91 \%$ of compliance related to the flexibility aspect. This means less effort to assemble and disassemble parts and is an important aspect with regards to innovation.

This paper also presented a new application for the protocol developed by Peñaloza, Formoso and Saurin (2017). Although the protocol had been originally devised to assess the TEPS requirements concerning the design and use in construction sites, it also proved to be useful to assess patents. Nevertheless, one of the possible reasons for the relatively low scores of many assessed patents may be the fact that the protocol's requirements were originally defined having in mind TEPS designs to be used in specific construction sites in order to offer practical guidance to workers and supervisors. In fact, patent documents tend to be much less detailed than the designs. This low level of detail may be intentional, as the inventors may be interested in maintaining secrecy of some practical details and maintaining market advantage, despite patent protection.

\section{Conclusions}

Among the objectives proposed in this article, the tasks of selecting patents and the main innovations of patents related to TEPS were both fulfilled. Moreover, the framework proposed in this research is an applicable and innovative resource to disseminate techniques included in TEPS patent databases .

Among the difficulties and limitations of the patent study, the non-existence of original documents available for study, the lack of specific information in a significant amount of patents, such as the weight of the equipment and material strength data, as well as the large number of inventions submitted in languages other than English, Portuguese and Spanish, especially in Chinese, should be mentioned.

Moreover, the conclusion can be drawn that patent documents are a valuable source of technological information when searching for improvements in TEPS and that if the measurement settings are implemented effectively, especially those related to the national regulatory standards, they can minimise the safety problems currently faced in construction sites.

As an opportunity for future studies, the requirements set by the framework could be adapted to the regulations of other countries. As a result, the sizes, thicknesses and materials to be used in the TEPS could be defined as additional requirements. Furthermore, similar frameworks could be developed to support the selection and analysis of innovation in other construction safety equipment and tools.

\section{References}

AFETAL, D. B. Equipamento de Proteção Contra Queda com Rede de Segurança para Construção Civil. INPI, BR202013023708, 16 set. 2013.

AMADON, C. et al. Fall Protection System. European Patents, US2014102829, 15 out. 2012.

ASSOCIAÇÃO BRASILEIRA DE NORMAS TÉCNICAS. NBR 14718: guarda-corpo para edificação. Rio de Janeiro, 2001.

ASOCIACIÓN ESPAÑOLA DE NORMALIZACIÓN Y CERTIFICACIÓN. UNEEN 13374: sistemas provisionales de protección de borde. Madrid, 2004.

BLINN, L. Safety Barrier Netting System with Rigid Panel Net Supports and Stopper Mechanisms. European Patents, US20140339018, 4 Jan. 2012.

BRASIL. Ministério do Trabalho e Emprego. NR 18: condições e meio ambiente de trabalho na indústria da construção. Brasília: MTE, 2015.

BRASIL. Ministério do Trabalho e Emprego. NR 35: trabalho em altura. Brasília: MTE, 2012.

BRÖCHNER, J. Construction patents and university-industry research interaction: an analysis of Nordic region data. Construction Innovation, v. 13, n. 4, p. 410-423, 2013.

BUDZIAK, A.; BUDZIAK, C.; BUDZIAK, G. Nsafe Engineering Inc. Building Roof Safety Assembly Having a Barrier and Ladder Restraint. European Patents, US20150027812, 24 jul. 2013.

CAMERON, I.; DUFF, R.; GILLAN, G. A Technical Guide to the Selection and Use of Fall Prevention and Arrest Equipment. Glasgow: Health and Safety Executive, 2005.

CHILTON, R. W. National Trench Safety. Safety

Rail System and Method for Using Same.

European Patents, US20140374682, 25 Jan. 2011. 
CORREDOIRA, R.; BANERJEE, P. M.

Measuring Patent's Influence on Technological Evolution: a study of knowledge spanning and subsequent inventive activity. Social Science Research Network, v. 44, n. 2, p. 508-521, mar. 2015.

COSTELLA, M. F.; JUNGES, F. C.; PILZ, S. E. Avaliação do Cumprimento da NR-18 em Função do Porte de Obra Residencial e Proposta de lisTa de Verificação da NR-18. Ambiente Construído, Porto Alegre, v. 14, n. 3, p. 87-102, jul./set. 2014.

DELIC, J.; PAPAYIANNERIS, S. Safety Barrier. European Patents, AU2011100248, May 2010.

DITTA, J.; DITTA, P. L.; DITTA, V. Removable Safety Barrier. European Patents, US20140191174, 10 Jul. 2014.

DROZD, W.; KOWALIK, M. Modern Safety Systems for Work at Height. Czasopismo Techniczne, v. 5, n. 1-B, p. 247-254, 2014.

FAGUNDES, M. C. et al. Perfil Tecnológico da CSN: um estudo patentométrico. Revista de Administração e Inovação, v. 11, n. 1, p. 276294, 2014.

FEDERMAN, S. R. Patentes: desvendando seus mistérios. Rio de Janeiro: Qualitymark, 2006.

FRITSCH, J.; ROBERTS, M. L. Garlock Equipment Company. Safety Rail System. European Patents, US8632056, 4 fev. 2013.

FUNDACENTRO. Recomendação Técnica de Procedimentos: medidas de proteção contra quedas de altura. São Paulo: MTE, 2003.

GAMBATESE, J. A.; HALLOWELL, M. Enabling and Measuring Innovation in the Construction Industry. Construction

Management and Economics, v. 29, n. 6, p. 553567, Jun. 2011.

HARDIE, M.; NEWELL, G. Factors Influencing Technical Innovation in Construction SMEs: an Australian perspective. Engineering, Construction andArchitectural Management, v. 18, n. 6, p. 618-636, 2011.

INSTITUTO NACIONAL DA PROPRIEDADE INDUSTRIAL. Propriedade Industrial Aplicada: reflexões para o magistrado. Brasília: INPI, 2013.

JACOSKI, C. A.; COSTELlA, M. F.; RIGON, M. Estudo Patentométrico de Argamassas no Brasil. In: ENCONTRO NACIONAL DE TECNOLOGIA DO AMBIENTE CONSTRUÍDO, 5, Maceió, 2014. Anais... Maceió: ENTAC, 2014.
JARRETT, J. S.; STREET, G.; WARNAMBOOL, V. Riser Safety Arrangement for Open Stairs. European Patents, WO2014194359, 7 Jun. 2013.

LAN, A.; DAIGLE, R. Development and Validation of a Method for Evaluating Temporary Wooden Guardrails Built and Installed on Construction Sites. Safety Science, v. 47, n. 2, p. 215-226, Feb. 2009.

MARK, T. Perimeter Screen with Rotating Debris Retainer. European Patents, GB2491193, 27 May 2011.

MAZIERI, M. R.; QUONIAM, L.; SANTOS, A. M. Inovação a Partir das Informações de Patentes: proposição de modelo open source de extração de informações de patentes (Patent Crawler). Revista Gestão \& Tecnologia, v. 16, n. 1, p. 103-139, jan./abr. 2016.

NOVAES, R. S. C. de. Sistema de Proteção para Obras. Instituto Nacional da Propriedade Industrial, BR 102012028744 7, 09 nov. 2012.

OCCUPATIONAL SAFETY \& HEALTH ADMINISTRATION. United States Department of Labour. 1926. 502 - Fall protection systems criteria and practices. 1996. Available at: <https://www.osha.gov/pls/oshaweb/owadisp.show _document?p_table=

STANDARDS\&p_id=12759>. Accessed on: 25 Aug. 2015.

OFICINA ESPAÑOLA DE PATENTES Y MARCAS. Las Patentes Como fuente de Información Tecnológica. Madrid: OEPM, 2012.

ORGANIZAÇÃO INTERNACIONAL DO TRABALHO. Doenças Profissionais São Principais Causas de Mortes no Trabalho. Brasília, 2013. Available at: http://www.oitbrasil.org.br/content/doencasprofissionais-sao-principais-causas-de-mortes-notrabalho. Accessed on: 15 Jun. 2015.

OUELLETTE, L. L. Do Patents Disclose Useful Information? Harvard Journal of Law and Technology, v. 25, n. 2, p. 545-607, 2012.

OZORHON, B. et al. Innovation in Construction: a project life cycle approach. Salford: Salford Centre for Research and Innovation in the built and human environment, 2010 .

PAVANELLI, M. A.; OLIVEIRA, E. F. T. Conhecimento Tecnológico e Inovação no Brasil: um estudo patentométrico na Universidade Estadual Paulista (Unesp). Ibersid, v. 6, n. 1, p. 119-125, 2012. 
PEÑALOZA, G. A.; FORMOSO, C. T.; SAURIN, T. A. Identification and Assessment of Requirements of Temporary Edge Protection Systems for Buildings. International Journal of Industrial Ergonomics, 2017.

RAMON, X. Fence for Use as Barrier Installation. European Patents, US2014091269, 01 out. 2012.

ROSATI, W. Improved Frame for Climbing Screen. European Patents, AU2013284343, 26 Jun. 2012.

SIDLA, J. G.; STOFFELS, R. B. Safety Rail System. European Patents, US2014217345, Mar. 2014.

SILVA, A. M. da. Sistema Limitador de Queda de Altura com Rede de Proteção. INPI, PI11022574, 10 May 2011.

SMITH, G. Safety System. United States Patents, US20110179744, 28 Jul. 2011.

SONG, L. Scaffolding Safety Mesh. European Patents, AU2012248112, 27 Apr. 2011.

SOUZA, R. R; TEIXEIRA, R. C. O Uso das Informações Contidas em Documentos de Patentes nas Práticas de INTELIGÊNCIA Competitiva: apresentação de um estudo das patentes da UFMG. Perspectivas em Ciência da Informação, v. 18, n. 1, p. 106-125, jan./mar. 2013.
SVEDBERG, J. Combisafe International Aktiebolag. Safety Barrier. United States Patents, US20130001493, 03 Jan. 2013.

TOOLE, T.; CARPENTER, G. Prevention Through Design: an important aspect of social sustainability. In: INTERNATIONAL CONFERENCE ON SUSTAINABLE DESIGN AND CONSTRUCTION, Kansas City, 2011. Proceedings... New York: ASCE, 2011.

TRUSH, S. R.; VOS, D. A.; WHITE, I. K. A Modular Barrier System. European Patents, WO2014134687, 07 Mar. 2013.

XUE, X. et al. Innovation in Construction: a critical review and future research. International Journal of Innovation Science, v. 6, n. 2, p. 111 125 , jun. 2014.

WILLIAMS, E. G. G. Safety Guard Rail. European Patents, WO2014019084, 30 Jul. 2012.

WORLD INTELLECTUAL PROPERTY ORGANIZATION. Learn From the Past, Create the Future: inventions and patents. Geneva: WIPO, 2007.

Letícia Nonnenmacher

Programa de Pós-Graduação em Tecnologia e Gestão da Inovação | Universidade Comunitária da Região de Chapecó | Av. Atilio Fontana, 591E, Efapi | Chapecó - SC - Brasil | CEP 89801-015 | Tel.: (49) 3321-8290 | E-mail: letician@unochapeco.edu.br

Marcelo Fabiano Costella

Faculdade Meridional IMED | Universidade Comunitária da Região de Chapecó | E-mail: costella@unochapeco.edu.br

Monike de Medeiros Costella

Programa de Pós-Graduação em Tecnologia e Gestão da Inovação | Universidade Comunitária da Região de Chapecó |

E-mail: monike@unochapeco.edu.br

Tarcisio Abreu Saurin

Programa de Pós Graduação Em Engenharia de Produção | Universidade Federal do Rio Grande do Sul | Av. Osvaldo Aranha, $99,5^{\circ}$ andar, Bom Fim | Porto Alegre - RS - Brasil | CEP 90035-190 | Tel.: (51) 3308-4299 | E-mail: saurin@ufrgs.br

Revista Ambiente Construído

Associação Nacional de Tecnologia do Ambiente Construído

Av. Osvaldo Aranha, $99-3^{\circ}$ andar, Centro

Porto Alegre - RS - Brasil

CEP 90035-190

Telefone: +55 (51) 3308-4084

Fax: +55 (51) 3308-4054

www.seer.ufrgs.br/ambienteconstruido

E-mail: ambienteconstruido@ufrgs.br 